\title{
On farm demonstration of zero tillage maize in farmers fields of Anantapuram district of Andhra Pradesh
}

\author{
C. RADHA KUMARI* AND M. JOHN SUDHEER \\ District Agricultural Advisory and Transfer of Technology Centre, ANANTAPURAM (A.P.) INDIA \\ (Email : radhaphd@yahoo.in)
}

\begin{abstract}
On farm demonstrations were conducted in farmers fields to popularize zero tillage maize technology among farmers under supervision of DAATT Centre (Extension unit of Acharya N.G. Ranga Agricultural University, Andhra Pradesh), Anantapuram for four years during Rabi, 2011-12, 2012-13, 2013-14 and 2014-15. The comparison was made between zero tillage maize and farmers practice (traditional maize cultivation) with an objective to obtain higher maize productivity and net returns in farmers fields under zero tilled conditions. Results revealed that higher cob length of $17.4 \mathrm{~cm}$ was recorded with zero tillage maize compared to farmers practice $(15.5 \mathrm{~cm})$. Higher grain weight per plant of $129 \mathrm{~g}$ was recorded with zero tillage maize compared to farmers practice ( $115 \mathrm{~g}$ ). There were more number of grains per cob (421) in zero tillage maize as compared to 385 grains per cob in farmers practice. Higher 100 grain weight of $26.2 \mathrm{~g}$ was recorded with zero tillage maize compared to farmers practice (23.6 g). In zero tillage maize cob length, grain weight / plant, number of grains/cob and 100 grain weight were increased by 12.3, 12.2, 9.4 and 11.0 per cent, respectively over farmers practice. Zero tillage maize recorded higher grain yield $\left(6250 \mathrm{~kg} \mathrm{ha}^{-1}\right)$ and stover yield (7750 $\mathrm{kg} \mathrm{ha}^{-1}$ ) which was 11.4 and 6.9 per cent, respectively higher over farmers practice $\left(5610 \mathrm{~kg} \mathrm{ha}^{-1}\right.$ grain yield and $7250 \mathrm{~kg} \mathrm{ha}^{-1}$ stover yield). Gross returns (Rs. 93,750/-) and net returns (Rs. 78,000/-) per hectare were more with zero tillage maize compared to farmers practice (Rs. 84,150/- gross returns and Rs. 62,500/-net returns). Simultaneously cost benefit ratio was higher with zero tillage maize (1:5.9) compared to farmers practice (1:3.9) because of lower cost of cultivation and improved yield with zero tillage maize. In zero tillage maize cost of cultivation was reduced by 27.3 per cent whereas, gross returns and net returns were improved by 11.4 and 24.8 per cent, respectively over farmers practice.
\end{abstract}

Key Words : : On farm demonstration, Zero tillage maize, Farmers fields

View Point Article : Kumari, C. Radha and Sudheer, John M. (2016). On farm demonstration of zero tillage maize in farmers fields of Anantapuram district of Andhra Pradesh. Internat. J. agric. Sci., 12 (1) : 134-138.

Article History : Received : 15.09.2015; Accepted : 26.12.2015

\footnotetext{
* Author for correspondence : Agricultural Research Station, ANANTAPURAM (A.P.) INDIA
} 